\title{
Chemical and spectroscopic characterization of tourmalines from the Mata Azul pegmatitic field, Central Brazil
}

\author{
Simone F. da SILVA ${ }^{1,2 *}$, Márcia A. MOURA², Hudson de A. QUEIROZ², José D. ARDISSON³ \\ ${ }^{1}$ Instituto Federal de Minas Gerais, Campus Congonhas, Avenida Michel Pereira de Souza, 3007, Campinho, 36415-000 Congonhas, Minas \\ Gerais, Brazil; simone.geologia@gmail.com \\ ${ }^{2}$ Instituto de Geociências, Universidade de Brasília, Campus Darcy Ribeiro, Asa Norte, 70910-900 Brasília, Distrito Federal, Brazil \\ ${ }^{3}$ Centro de Desenvolvimento de Tecnologia Nuclear (CDTN), Laboratório de Física Aplicada, Rua Prof. Mário Wernec, 30161970, Belo \\ Horizonte, Minas Gerais, Brazil \\ * Corresponding author
}

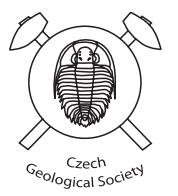

This study characterizes natural black, blue, dark green, light green and pink tourmalines from granitic pegmatites of the Mata Azul Pegmatitic Field in central Brazil. The differences were assessed by applying electron-microprobe analysis as well as Mössbauer and optical spectroscopies. Mineral chemistry data show an increasing $\mathrm{Mn} /(\mathrm{Mn}+\mathrm{Fe})$ atomic ratio as follows: black (0.01-0.02), blue (0.04-0.05), dark green (0.09-0.21), light green (0.33-0.42) and pink $(0.68-1.00)$. The Mössbauer spectroscopy results show the presence of $\mathrm{Fe}^{2+}$ (doublets with isomer shift $(\delta): 1.04-1.15 \mathrm{~mm} / \mathrm{s}$ ) for the black, blue, light green and dark green tourmalines. $\mathrm{Fe}^{2+}$ is found in three different environments that are identified by quadrupole splitting $(\Delta)$ of $2.38-2.49 \mathrm{~mm} / \mathrm{s}$ for the first, $\Delta=2.13-2.34 \mathrm{~mm} / \mathrm{s}$ for the second, and $\Delta=1.54-1.71 \mathrm{~mm} / \mathrm{s}$ for the third. The black sample spectrum has an additional fourth doublet $(\delta=0.78 \mathrm{~mm} / \mathrm{s}, \Delta=1.22 \mathrm{~mm} / \mathrm{s})$ that is assigned to an electron delocalization between $\mathrm{Fe}^{2+}$ and $\mathrm{Fe}^{3+}$.

In the studied samples, the black color results most likely from high absorbance in all the visible spectra caused by $\mathrm{Fe}^{2+}-\mathrm{Fe}^{3+}$ intervalence charge transfer (IVCT) $(780 \mathrm{~nm}), \mathrm{Fe}^{2+} \mathrm{d}-\mathrm{d}$ transitions $(730 \mathrm{~nm}, 670 \mathrm{~nm}), \mathrm{Fe}^{2+}-\mathrm{Ti}^{4+}$ IVCT $(430 \mathrm{~nm})$ and transitions related to $\mathrm{Mn}$ cations $(550 \mathrm{~nm})$. Blue is differentiated from green colors by a higher absorbance in the $730 \mathrm{~nm}$ region ( $\mathrm{Fe}^{2+} \mathrm{d}-\mathrm{d}$ transitions), and a higher $\mathrm{FeO}$ content, as well as a lower absorbance in the $430 \mathrm{~nm}$ region and a lower $\mathrm{TiO}_{2}$ content. The green colors are associated with the absorption bands at $730 \mathrm{~nm}\left(\mathrm{Fe}^{2+} \mathrm{d}-\mathrm{d}\right.$ transitions) and $430 \mathrm{~nm}\left(\mathrm{Fe}^{2+}-\mathrm{Ti}^{4+}\right.$ IVCT). The light green color exhibited a lower intensity of these bands compared to that of the dark green color, and an additional band at $320 \mathrm{~nm}\left(\mathrm{Mn}^{2+}-\mathrm{Ti}^{4+}\right.$ IVCT). The pink color results from the high degree of $\mathrm{Mn}-\mathrm{Fe}$ fractionation but it was not possible to assure the oxidation states of the Mn cations.

Keywords: mineral color, tourmaline, electron microprobe, Mössbauer spectroscopy, optical spectroscopy

Received: 28 September, 2017; accepted: 1 June, 2018; handling editor: J. Cempirek

The online version of this article (doi: 10.3190/jgeosci.258) contains supplementary electronic material.

\section{Introduction}

Tourmaline-supergroup minerals are borosilicates with a complex structure where a large variety of chemical elements can be incorporated by simple or coupled substitutions. For this reason, tourmalines feature a wide range of colors and are frequently used as a gemstone. The general formula of tourmaline-supergroup minerals is $X Y_{3} Z_{6} T_{6} \mathrm{O}_{18}\left(B \mathrm{O}_{3}\right)_{3} V V_{3} \mathrm{~W}$, where the most common ions or vacancies $(\square)$ at the individual sites are: $X=\mathrm{Na}^{+}, \mathrm{Ca}^{2+}$, $\mathrm{K}^{+}$or $\square, Y=\mathrm{Fe}^{2+}, \mathrm{Mg}^{2+}, \mathrm{Mn}^{2+}, \mathrm{Al}^{3+}, \mathrm{Li}^{1+}, \mathrm{Fe}^{3+}, \mathrm{Cr}^{3+}, \mathrm{Ti}^{4+}$ and $\mathrm{V}^{3+}, Z=\mathrm{Al}^{3+}, \mathrm{Fe}^{3+}, \mathrm{Mg}^{2+}, \mathrm{Cr}^{3+}$, and $\mathrm{V}^{3+}, T=\mathrm{Si}, \mathrm{Al}$ and $\mathrm{B}, B=\mathrm{B}, V=\mathrm{OH}^{-}$and $\mathrm{O}^{2-}, W=\mathrm{OH}^{-}, \mathrm{F}^{-}$and $\mathrm{O}^{2-}$ (Henry et al. 2011; Henry and Dutrow 2012).

The color of tourmaline-supergroup minerals is influenced mainly by amount of transition metal cations and their distribution between the $Y$ and $Z$ sites, in some cases also by the presence of electron or hole traps (Krambrock et al. 2004). Therefore, full chemical and spectroscopic characterization of tourmalines is essential in order to determine the cause of their color; this has been topic of many studies (e.g., Castañeda 2002; Krambrock et al. 2002, 2004; Liu et al. 2011; Taran et al. 2015; Maneewong et al. 2016).

In this paper, we present a study on causes of color in tourmalines from the Mata Azul Pegmatitic Field, Tocantins and Goias, central Brazil (Queiroz 2016, Queiroz and Botelho in print). We performed chemical and spectroscopic characterization of the tourmalines using electron-microprobe analysis (EMPA) optical spectroscopy in ultraviolet-visible range (UV-VIS) and Mössbauer spectroscopy, which are all well-established techniques in tourmaline color characterization. This is the first advanced multi-analytical study on tourmalines from the Mata Azul region, an important artisanal mining district in Brazil in the 1980s. 


\section{Geological setting}

The Mata Azul Pegmatitic Field (central Brazil) (Queiroz 2016, Queiroz and Botelho in print) is located in the extensive Northern Brasília Fold Belt (Dardenne 2000; de Almeida et al. 1981), which is part of the Neoproterozoic Tocatins Province. This is a major orogenic system built by the Araguaia, Paraguaia and Brasília belts formed due to the collision of the Amazon Craton, the São Francisco Craton and the Paranapanema Block (Valeriano et al. 2004).

The Mata Azul Pegmatitic Field was defined by Queiroz (2016), who distinguished and characterized in detail barren pegmatites, beryl-bearing pegmatites and tourmaline-bearing pegmatites, typically with exposures ranging from tens to hundreds of square meters. Based on the Černý and Ercit (2005) classification, both the beryl- and the tourmaline-bearing pegmatites belong to the rare-element (REL) class and the REL-Li subclass of granitic pegmatites; most of the pegmatites once explored for tourmaline in this region belong to the complex type and classify as elbaite-subtype pegmatites, and most of those explored for beryl belong to the beryl type, berylcolumbite-phosphate subtype. Their source is considered to be the Mata Azul granitic Suite. They are intrusive in the metasedimentary rocks of the Serra da Mesa Group and the Ticunzal Fm. as well as in the peraluminous granites of the Aurumina Suite (Queiroz 2016; Queiroz and Botelho 2017, in print; Fig. 1). The Ticunzal Fm. and the Aurumina Suite are part of the basement of the Northern Brasília Belt external zone.

The Ticunzal Fm. is dominated by paragneisses and mica-graphite schists, with mineral assemblages indicating retrograde metamorphism under greenschist-facies conditions, and also presents tourmaline schists, minor quartzites and rare metaconglomerates. The Aurumina Suite is composed of peraluminous granites, tonalities/ granodiorites with mineral assemblage of magmatic muscovite \pm biotite \pm garnet and discrete xenocrystic graphite lamellae. These granitic rocks are intrusive in the Ticunzal $\mathrm{Fm}$. and have $\mathrm{U}-\mathrm{Pb}$ ages on zircon between 2.11 and $2.16 \mathrm{Ga}$ (Alvarenga et al. 2007; Cuadros et al. 2017a, b).

The Serra da Mesa Group has been interpreted as a metamorphosed marine sequence where sediments were deposited in a silicic-carbonate platform (Marques 2009) between 1.57 and $1.47 \mathrm{Ga}$ (Dardenne 2000).

The Mata Azul Suite is composed of granites containing quartz, perthitic microcline, oligoclase, muscovite, biotite, tourmaline, beryl, garnet and tantalite and posttectonic pegmatites (Lacerda Filho et al. 1999; Polo and Diener 2013). Some leucogranites in this unit were classified by Queiroz (2016) as peraluminous with geochemical signatures typical of LCT granites and pegmatites, following Černý $(1990,1991)$. Recently, Queiroz and
Botelho (in print) reported $\mathrm{U}-\mathrm{Pb}$ ages on monazite of $519.9 \pm 2.8 \mathrm{Ma}$ in a pegmatite which was related to this unit.

\section{Materials and methods}

\subsection{Samples}

The tourmaline crystals were acquired from the mineralogical collection at the Institute of Geosciences of the University of Brasília. The samples are from central Brazil, in an area recently defined as the Mata Azul Pegmatitic Field by Queiroz (2016), where in the past, some pegmatites were intensely explored and produced gemstone varieties of tourmaline and beryl. However, there is no further information about the exact sampling location.

Five different types of tourmaline samples were studied:

- MA5: black tourmaline,

- MA5G: blue tourmalines,

- MA1G: dark green tourmalines,

- MA0: light green tourmalines,

- MA8: pink tourmalines.

Thin sections were made of one sample from each group. Each section was coated with a $25 \mathrm{~nm}$-thick carbon film for electron microprobe analysis.

Several tourmaline crystals from each group were finely ground together using an agate mortar and pestle, with the exception of MA5 for which only one crystal was used. The powder material was then used for Mössbauer and UV-VIS spectroscopy analyses.

\subsection{Electron-microprobe analyses}

The chemical composition of tourmalines was analyzed with a JEOL JXA-8230 electron microprobe at the Electron Microprobe Laboratory in the Institute of Geosciences of the University of Brasilia, with wavelengthdispersive spectrometer system operating at an accelerating potential of $15 \mathrm{kV}$ and a beam current of $10^{-8} \mathrm{~A}$. The samples were analyzed using the following standards: albite $(\mathrm{Na})$, forsterite $(\mathrm{Mg})$, topaz $(\mathrm{F})$, anorthite $(\mathrm{Al})$, microcline $(\mathrm{Si}, \mathrm{K})$, andradite $(\mathrm{Ca}, \mathrm{Fe})$, vanadinite $(\mathrm{Cl}$, V), pyrophanite ( $\mathrm{Ti}, \mathrm{Mn}), \mathrm{Cr}_{2} \mathrm{O}_{3}(\mathrm{Cr})$ and $\mathrm{ZnO}(\mathrm{Zn})$. The detection limits were up to 0.01 wt. $\%$ for $\mathrm{Cl} ; 0.01 \mathrm{wt}$ \% for $\mathrm{Na}, \mathrm{Mg}, \mathrm{Al}, \mathrm{Si}, \mathrm{Ca}, \mathrm{K}, \mathrm{Fe}$ and $\mathrm{V}$; 0.02 wt. \% for $\mathrm{Zn}$; $0.01-0.02$ wt. \% for $\mathrm{Mn}$ and F, $0.01-0.03$ wt. \% for $\mathrm{Cr}$ and $0.02-0.05 \mathrm{wt}$. \% for Ti. The mineral formulae were calculated based on 31 anions $(\mathrm{O}, \mathrm{OH}, \mathrm{F})$, assuming $\mathrm{B}=$ 3 apfu (atoms per formula unit), $(\mathrm{OH}+\mathrm{F})=4 a p f u$ and $\mathrm{Li}=15-(T+Z+Y)$ using the Excel ${ }^{\mathrm{TM}}$ worksheet of Tindle et al. (2002). Finally, all formulae were classified according to the rules of Henry et al. (2011). 


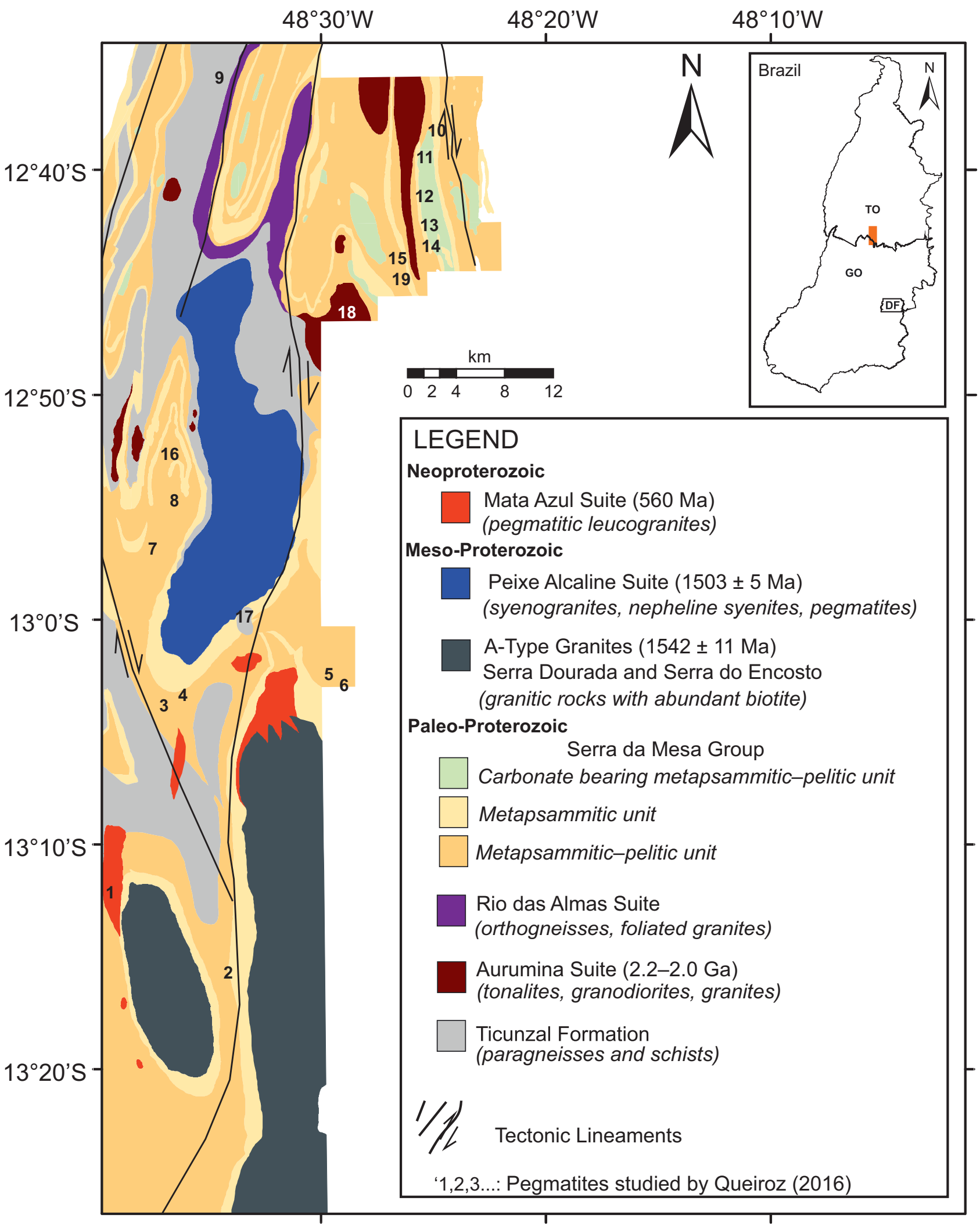

Fig. 1 Geological map of the Mata Azul Pegmatitic Field area with specific pegmatites studied by Queiroz (2016) represented with the numbers. 1: Levantina quarry, 2: Córrego das Pedras, 3: Jóia da Mata, 4: "four", 5: "five", 6: "six", 7: São Júlio, 8: Pichorra, 9: Fazenda Mesquita, 10: Berilão, 11: Marta Rocha, 12: Zé do Fole, 13: Índio, 14: Boanerges, 15: Marimbondo, 16: "sixteen”, 17: "seventeen", 18: Onça, 19: Marimbondinho (Queiroz and Botelho in print). 


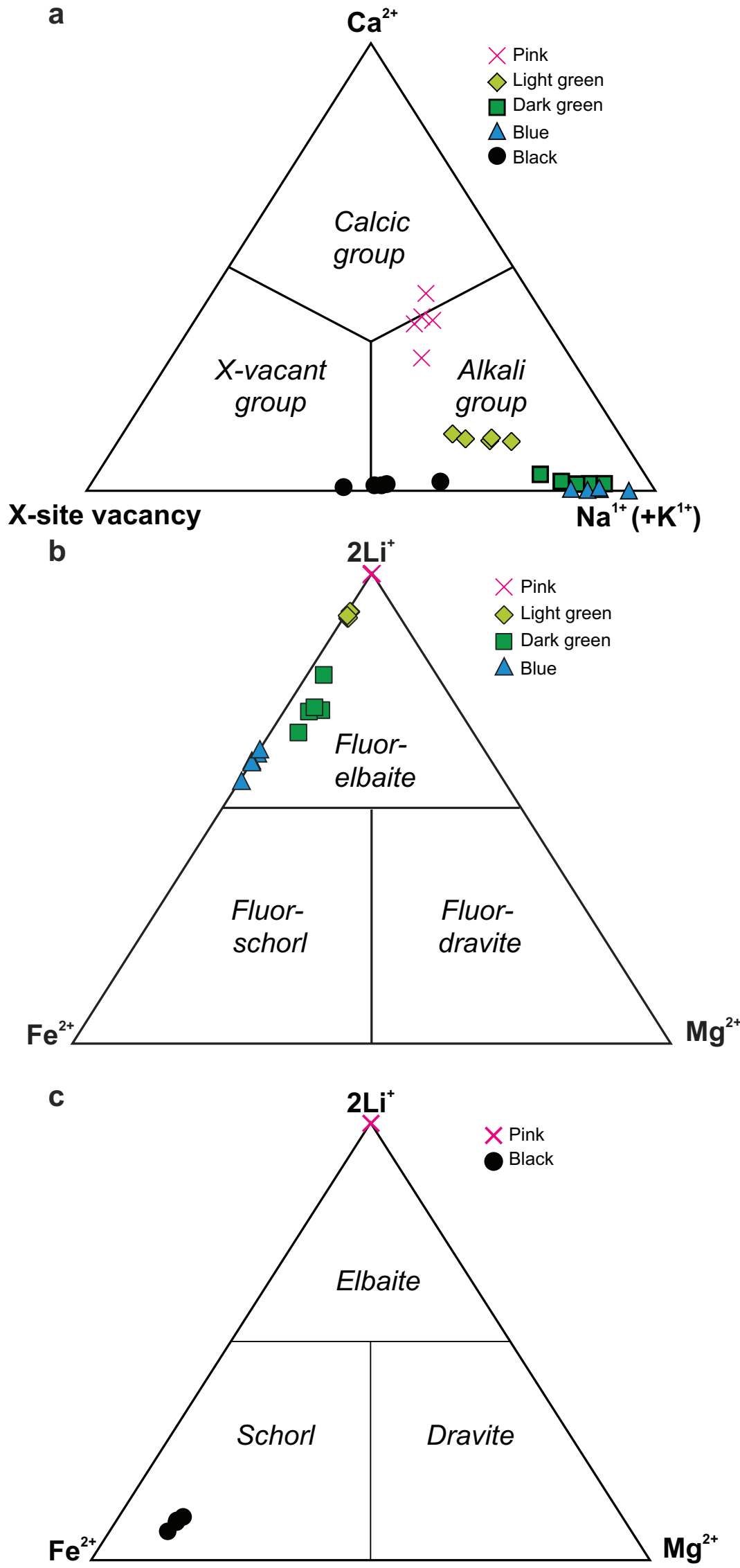

\subsection{Mössbauer spectroscopy}

Mössbauer spectra were acquired at room temperature $(298 \mathrm{~K})$ using a conventional spectrometer system with a ${ }^{57} \mathrm{Co} / \mathrm{Rh}$ source providing an activity of $95 \mathrm{mCi}$ at the Nuclear Technology Development Center (CDTN), Minas Gerais, Brazil. Analytical data were recorded in a multichannel analyzer using 1024 channels for the variable velocity range. The run-times were often 1-2 days; however, one week was used for the sample with the lowest Fe content. The isomer shifts and the velocity scale were calibrated against $\alpha$-Fe foil at room temperature.

\subsection{Optical spectroscopy in ultraviolet-visible range (UV-VIS)}

The UV-VIS optical absorption spectra of the powder samples were obtained in the spectral range of $200-800 \mathrm{~nm}$ (50000-12500 $\left.\mathrm{cm}^{-1}\right)$ using a UV 3600 Shimadzu spectrometer at the Department of Physics of the Federal University of Minas Gerais.

\section{Results}

\subsection{Electron-microprobe analyses}

The compositions of tourmaline samples are slightly heterogeneous in terms of both $X$ - and $Y$-site occupancies (Fig. 2). All tourmalines belong to the alkali group with $X$-site dominated by $\mathrm{Na}$, except two outlying points (Fig. 2a). The amount of $X$-site vacancy decreases from black, through green to blue tourmalines; the pink tourmaline has high contents of $\mathrm{Ca}$ as well as elevated amount of $X$-site vacancy (Fig. 2a). The W-site occupancy

Fig. 2 Classification diagrams for tourmaline; a - Diagram based on the occupancy of the $X$ site, b - Ternary fluor-dravite-fluor-schorl-fluor-elbaite subsystem, and $\mathbf{c}$ - Ternary dravite-schorl-elbaite subsystem (Henry et al. 2011). The points corresponding to fluor-liddicoatite and foitite are not represented in the final graphics. 
Tab. 1 Representative electron-microprobe analyses of black, blue, dark green, light green and pink tourmalines (wt. \% and apfu)

\begin{tabular}{|c|c|c|c|c|c|}
\hline & Black & Blue & Dark green & Light green & Pink \\
\hline $\mathrm{SiO}_{2}$ & 35.03 & 36.23 & 37.05 & 38.34 & 36.70 \\
\hline $\mathrm{TiO}_{2}$ & 0.24 & b.d.1. & 0.36 & 0.30 & 0.06 \\
\hline $\mathrm{Al}_{2} \mathrm{O}_{3}$ & 34.20 & 35.99 & 37.50 & 39.24 & 40.40 \\
\hline $\mathrm{V}_{2} \mathrm{O}_{3}$ & 0.03 & b.d.1. & 0.04 & b.d.l. & 0.03 \\
\hline $\mathrm{Cr}_{2} \mathrm{O}_{3}$ & b.d.l. & 0.07 & 0.05 & b.d.l. & b.d.l. \\
\hline $\mathrm{FeO}$ & 14.06 & 8.73 & 4.76 & 1.91 & 0.05 \\
\hline $\mathrm{MgO}$ & 1.11 & 0.04 & 0.71 & 0.03 & 0.01 \\
\hline $\mathrm{CaO}$ & 0.12 & 0.01 & 0.12 & 0.70 & 2.17 \\
\hline $\mathrm{MnO}$ & 0.24 & 0.40 & 0.57 & 0.93 & 0.59 \\
\hline $\mathrm{ZnO}$ & 0.07 & 0.33 & 0.07 & 0.06 & 0.08 \\
\hline $\mathrm{Na}_{2} \mathrm{O}$ & 1.87 & 2.75 & 2.64 & 2.13 & 1.26 \\
\hline $\mathrm{K}_{2} \mathrm{O}$ & 0.03 & 0.03 & 0.01 & 0.02 & 0.02 \\
\hline $\mathrm{F}$ & 0.27 & 1.38 & 1.20 & 1.26 & 1.10 \\
\hline $\mathrm{Cl}$ & b.d.l. & b.d.l. & b.d.l. & 0.01 & 0.01 \\
\hline $\mathrm{H}_{2} \mathrm{O}^{*}$ & 3.47 & 3.00 & 3.16 & 3.22 & 3.24 \\
\hline $\mathrm{B}_{2} \mathrm{O}_{3} *$ & 10.42 & 10.58 & 10.81 & 11.06 & 10.90 \\
\hline $\mathrm{Li}_{2} \mathrm{O}^{*}$ & 0.18 & 1.16 & 1.53 & 2.08 & 2.26 \\
\hline Total & 101.33 & 100.68 & 100.57 & 101.29 & 98.85 \\
\hline $\mathrm{O}=\mathrm{F}$ & 0.11 & 0.58 & 0.50 & 0.53 & 0.46 \\
\hline Total* & 101.21 & 100.10 & 100.07 & 100.76 & 98.39 \\
\hline \multicolumn{6}{|c|}{ Structural formulae based on 31 anions $(\mathrm{O}, \mathrm{OH}, \mathrm{F})$} \\
\hline$T: \mathrm{Si}$ & 5.84 & 5.95 & 5.96 & 6.02 & 5.85 \\
\hline $\mathrm{Al}$ & 0.16 & 0.05 & 0.04 & - & 0.15 \\
\hline$B: \mathrm{B}$ & 3.00 & 3.00 & 3.00 & 3.00 & 3.00 \\
\hline$Z: \mathrm{Al}$ & 6.00 & 6.00 & 6.00 & 6.00 & 6.00 \\
\hline$Y: \mathrm{Al}$ & 0.57 & 0.92 & 1.06 & 1.26 & 1.45 \\
\hline $\mathrm{Ti}$ & 0.03 & b.d.l. & 0.04 & 0.04 & 0.01 \\
\hline $\mathrm{V}$ & b.d.1. & b.d.l. & 0.01 & b.d.l. & b.d.l. \\
\hline $\mathrm{Cr}$ & b.d.l. & 0.01 & 0.01 & b.d.l. & b.d.l. \\
\hline $\mathrm{Mg}$ & 0.28 & 0.01 & 0.17 & 0.01 & b.d.l. \\
\hline $\mathrm{Mn}$ & 0.03 & 0.05 & 0.08 & 0.12 & 0.08 \\
\hline $\mathrm{Fe}_{\text {total }}$ & 1.96 & 1.20 & 0.64 & 0.25 & 0.01 \\
\hline $\mathrm{Zn}$ & 0.01 & 0.04 & 0.01 & 0.01 & 0.01 \\
\hline $\mathrm{Li}^{*}$ & 0.12 & 0.77 & 0.99 & 1.31 & 1.45 \\
\hline$X: \mathrm{Ca}$ & 0.02 & b.d.l. & 0.02 & 0.12 & 0.37 \\
\hline $\mathrm{Na}$ & 0.60 & 0.87 & 0.82 & 0.65 & 0.39 \\
\hline $\mathrm{K}$ & 0.01 & 0.01 & b.d.1. & b.d.1. & b.d.1. \\
\hline$\square$ & 0.37 & 0.12 & 0.16 & 0.23 & 0.24 \\
\hline$V+W: \quad \mathrm{OH}$ & 3.86 & 3.28 & 3.39 & 3.37 & 3.45 \\
\hline F & 0.14 & 0.72 & 0.61 & 0.63 & 0.55 \\
\hline $\mathrm{Cl}$ & b.d.1. & b.d.l. & b.d.1. & b.d.l. & b.d.l. \\
\hline Species & Schorl & Fluor-elbaite & Fluor-elbaite & Fluor-elbaite & Fluor-elbaite \\
\hline
\end{tabular}

*Calculated by stoichiometry

All Fe was considered as FeO; b.d.1.= below detection limit; $\square$ = vacancy

is dominated by $\mathrm{F}$ in all samples except the ${ }^{\mathrm{w}} \mathrm{OH}$-dominated black tourmaline with low F (0.06-0.27 wt. \%) and one point of pink tourmaline. All samples show high Al contents $(6.72-7.73$ apfu $)$. The representative analyses are shown in Tab. 1. The complete set of analyses is attached (Electronic Supplementary Material).

Following Henry et al. (2011), the black crystal varies between the schorl (Fig. 2c) and foitite species, the blue, dark green and light green tourmalines are classified as fluor-elbaite (Fig. 2b), and the pink tourmaline is transi- tional among fluor-elbaite (Fig. 2b), elbaite (Fig. 2c) and fluor-liddicoatite.

The representative structural formulae are as follows: - black schorl:

$\left(\mathrm{Na}_{0.60} \square_{0.37} \mathrm{Ca}_{0.02} \mathrm{~K}_{0.01}\right)\left(\mathrm{Fe}_{1.96} \mathrm{Al}_{0.57} \mathrm{Mg}_{0.28} \mathrm{Li}_{0.12} \mathrm{Ti}_{0.03} \mathrm{Mn}_{0.03}\right.$ $\left.\mathrm{Zn}_{0.01}\right)\left(\mathrm{Al}_{6}\right)\left[\mathrm{Si}_{5.86} \mathrm{Al}_{0.14} \mathrm{O}_{18}\right]\left(\mathrm{BO}_{3}\right)_{3}(\mathrm{OH})_{3}\left(\mathrm{OH}_{0.86} \mathrm{~F}_{0.14}\right)$;

- blue fluor-elbaite:

$\left(\mathrm{Na}_{0.87} \square_{0.12} \mathrm{~K}_{0.01}\right)\left(\mathrm{Fe}_{1.20} \mathrm{Al}_{0.92} \mathrm{Li}_{0.77} \mathrm{Mn}_{0.05} \mathrm{Zn}_{0.04} \mathrm{Cr}_{0.01} \mathrm{Mg}_{0.01}\right)$ $\left(\mathrm{Al}_{6}\right)\left[\mathrm{Si}_{5.95} \mathrm{Al}_{0.05} \mathrm{O}_{18}\right]\left(\mathrm{BO}_{3}\right)_{3}(\mathrm{OH})_{3}\left(\mathrm{~F}_{0.72} \mathrm{OH}_{0.28}\right)$; 
Tab. 2 Transition metal contents (wt. \%) and $\mathrm{Mn} /(\mathrm{Mn}+\mathrm{Fe})$ atomic ratios in the black, blue, dark green, light green and pink tourmalines

\begin{tabular}{|c|c|c|c|c|c|c|}
\hline & $\mathrm{FeO}$ & $\mathrm{MnO}$ & $\mathrm{TiO}_{2}$ & $\mathrm{~V}_{2} \mathrm{O}_{3}$ & $\mathrm{Cr}_{2} \mathrm{O}_{3}$ & $\mathrm{Mn} /(\mathrm{Mn}+\mathrm{Fe})$ \\
\hline \multirow{5}{*}{ black } & 14.06 & 0.24 & 0.24 & 0.03 & b.d.l. & 0.02 \\
\hline & 13.85 & 0.13 & 0.25 & b.d.l. & 0.07 & 0.01 \\
\hline & 14.26 & 0.23 & 0.12 & 0.05 & b.d.l. & 0.02 \\
\hline & 13.94 & 0.21 & 0.14 & b.d.l. & 0.08 & 0.01 \\
\hline & 14.10 & 0.27 & 0.22 & b.d.l. & b.d.1. & 0.02 \\
\hline \multirow{5}{*}{ blue } & 8.27 & 0.42 & 0.15 & b.d.l. & 0.05 & 0.05 \\
\hline & 7.94 & 0.44 & b.d.1. & b.d.l. & b.d.l. & 0.05 \\
\hline & 8.73 & 0.40 & b.d.l. & b.d.l. & 0.07 & 0.04 \\
\hline & 8.23 & 0.31 & b.d.l. & b.d.l. & b.d.l. & 0.04 \\
\hline & 8.26 & 0.37 & b.d.l. & 0.01 & b.d.l. & 0.04 \\
\hline \multirow{5}{*}{$\begin{array}{l}\text { dark } \\
\text { green }\end{array}$} & 4.76 & 0.57 & 0.36 & 0.04 & 0.05 & 0.11 \\
\hline & 3.78 & 1.00 & 0.26 & b.d.l. & b.d.l. & 0.21 \\
\hline & 5.42 & 0.58 & 0.14 & b.d.l. & 0.02 & 0.10 \\
\hline & 4.91 & 0.73 & 0.12 & 0.03 & b.d.1. & 0.13 \\
\hline & 6.02 & 0.62 & 0.15 & b.d.1. & b.d.1. & 0.09 \\
\hline \multirow{5}{*}{$\begin{array}{l}\text { light } \\
\text { green }\end{array}$} & 1.67 & 1.18 & 0.11 & 0.04 & 0.06 & 0.42 \\
\hline & 1.79 & 1.11 & 0.03 & b.d.l. & 0.05 & 0.38 \\
\hline & 1.91 & 0.93 & 0.30 & b.d.l. & b.d.l. & 0.33 \\
\hline & 1.84 & 0.88 & 0.09 & 0.05 & b.d.1. & 0.33 \\
\hline & 1.88 & 0.97 & 0.07 & 0.04 & 0.05 & 0.34 \\
\hline \multirow{5}{*}{ pink } & b.d.l. & 0.27 & b.d.l. & b.d.l. & b.d.l. & 1.00 \\
\hline & 0.05 & 0.59 & 0.06 & 0.03 & b.d.1. & 0.93 \\
\hline & b.d.l. & 0.44 & b.d.l. & 0.02 & 0.05 & 1.00 \\
\hline & b.d.l. & 0.48 & b.d.l. & 0.01 & 0.04 & 1.00 \\
\hline & 0.05 & 0.11 & 0.03 & b.d.l. & b.d.1. & 0.68 \\
\hline
\end{tabular}

- dark green fluor-elbaite:

$\left(\mathrm{Na}_{0.82} \square_{0.16} \mathrm{Ca}_{0.02}\right)\left(\mathrm{Al}_{1.06} \mathrm{Li}_{0.99} \mathrm{Fe}_{0.64} \mathrm{Mg}_{0.17} \mathrm{Mn}_{0.08} \mathrm{Ti}_{0.04} \mathrm{~V}_{0.01}\right.$ $\left.\mathrm{Cr}_{0.01} \mathrm{Zn}_{0.01}\right)\left(\mathrm{Al}_{6}\right)\left[\mathrm{Si}_{5.96} \mathrm{Al}_{0.04} \mathrm{O}_{18}\right]\left(\mathrm{BO}_{3}\right)_{3}(\mathrm{OH})_{3}\left(\mathrm{~F}_{0.61} \mathrm{OH}_{0.39}\right)$;

- light green fluor-elbaite:

$\left(\mathrm{Na}_{0.65} \square_{0.23} \mathrm{Ca}_{0.12}\right)\left(\mathrm{Li}_{1.31} \mathrm{Al}_{1.26} \mathrm{Fe}_{0.25} \mathrm{Mn}_{0.12} \mathrm{Ti}_{0.04} \mathrm{Mg}_{0.01} \mathrm{Zn}_{0.01}\right)$ $\left(\mathrm{Al}_{6}\right)\left[\mathrm{Si}_{6.02} \mathrm{O}_{18}\right]\left(\mathrm{BO}_{3}\right)_{3}(\mathrm{OH})_{3}\left(\mathrm{~F}_{0.63} \mathrm{OH}_{0.37}\right)$;

- pink fluor-elbaite:

$\left(\mathrm{Na}_{0.39} \mathrm{Ca}_{0.37} \square_{0.24}\right)\left(\mathrm{Li}_{1.45} \mathrm{Al}_{1.44} \mathrm{Mn}_{0.08} \mathrm{Ti}_{0.01} \mathrm{Fe}_{0.01} \mathrm{Zn}_{0.01}\right)\left(\mathrm{Al}_{6}\right)$ $\left[\mathrm{Si}_{5.85} \mathrm{Al}_{0.15} \mathrm{O}_{18}\right]\left(\mathrm{BO}_{3}\right)_{3}(\mathrm{OH})_{3}\left(\mathrm{~F}_{0.55} \mathrm{OH}_{0.45}\right)$.

Table 2 summarizes ranges of contents of main chromophore transition metals found in the analyzed samples. The $\mathrm{FeO}$ content decreases in the following order: black (13.85-14.26 wt. \%), blue (7.94-8.73 wt. \%), dark green (3.78-6.02 wt. \%), light green (1.67-1.91 wt. \%), and pink (up to 0.05 wt. \%)

The light green sample has the highest $\mathrm{MnO}$ content $(0.88-1.18$ wt. \%), followed by dark green $(0.57-1.00$ wt. \%), pink (0.11-0.59 wt. \%), blue (0.31-0.44 wt. \%) and black (0.13-0.27 wt. \%). However, the only sample with greater $\mathrm{MnO}$ contents than those of $\mathrm{FeO}$ is the pink fluor-elbaite, which has the highest $\mathrm{Mn} /(\mathrm{Mn}+\mathrm{Fe})$ atomic ratio $(0.68-1.00)$, followed by the light green (0.33-0.42), dark green (0.9-0.21), blue (0.04-0.05) and black (0.01-0.02) samples.

The dark green sample has the highest $\mathrm{TiO}_{2}$ content (0.12-0.36 wt. \%), followed by the light green (up to 0.3 wt. \%), black (0.12-0.25 wt. \%), blue (up to 0.15 wt. \%) and pink samples (up to 0.06 wt. \%).

All the studied tourmalines show low contents of $\mathrm{V}_{2} \mathrm{O}_{3}$ (up to 0.05 wt. \%) and $\mathrm{Cr}_{2} \mathrm{O}_{3}$ (up to 0.08 wt. \%) or values below the detection limit of 0.01 wt. $\%$ for $\mathrm{V}_{2} \mathrm{O}_{3}$ and $0.01-0.03$ wt. $\%$ for $\mathrm{Cr}_{2} \mathrm{O}_{3}$

\subsection{Mössbauer spectroscopy}

The studied powder samples generated well-defined asymmetric doublet-shaped spectra (Fig. 3a-d), fitted with 3 or 4 doublets. The exception was the pink sample, from which it was not possible to acquire a spectrum, due to its very low iron content.

The hyperfine parameters for the analyzed tourmalines are listed in Tab. 3. All fitted

Tab. 3 Room-temperature ${ }^{57} \mathrm{Fe}$ Mössbauer parameters of the four analyzed tourmaline samples

\begin{tabular}{lccccc}
\hline Sample & $\delta(\mathrm{mm} / \mathrm{s})^{*}$ & $\Delta(\mathrm{mm} / \mathrm{s})$ & $\mathrm{T}(\mathrm{mm} / \mathrm{s})$ & $\mathrm{A}(\%)$ & Iron valence \\
\hline \multirow{4}{*}{ black } & 1.1 & 2.47 & 0.28 & 40.97 & $\mathrm{Fe}^{2+} Y 1$ \\
& 1.08 & 2.13 & 0.36 & 29.49 & $\mathrm{Fe}^{2+} Y 2$ \\
& 1.07 & 1.54 & 0.42 & 17.27 & $\mathrm{Fe}^{2+} Y 3$ \\
dark blue & 0.78 & 1.22 & 0.66 & 12.27 & $\mathrm{Fe}^{2.5+}$ \\
& 1.06 & 2.38 & 0.37 & 65.36 & $\mathrm{Fe}^{2+} Y 1$ \\
& 1.15 & 2.29 & 0.33 & 27.26 & $\mathrm{Fe}^{2+} Y 2$ \\
dark green & 1.06 & 1.28 & 0.57 & 7.38 & $\mathrm{Fe}^{2.5+} \mathrm{or} \mathrm{Fe}^{2+}(?)$ \\
\hline \multirow{3}{*}{ light green } & 1.04 & 2.49 & 0.33 & 29.07 & $\mathrm{Fe}^{2+} Y 1$ \\
& 1.11 & 2.34 & 0.33 & 61.77 & $\mathrm{Fe}^{2+} Y 2$ \\
& 1.13 & 1.71 & 0.43 & 9.16 & $\mathrm{Fe}^{2+} Y 3$ \\
\hline
\end{tabular}

Parameters of Mössbauer spectra:

$\delta$ - Isomer Shift, $\Delta-$ Quadrupole Splitting, $\tau$ - Peak Width, A - relative area *Calibrated on $\alpha-\mathrm{Fe}$ spectra provide three similar doublets, with the exception of the third doublet of blue tourmalines (isomer shift, $\delta=1.06$ $\mathrm{mm} / \mathrm{s}$ and quadrupole splitting, $\Delta=1.28 \mathrm{~mm} / \mathrm{s}$ ). The first common doublet has an $\delta$ varying between 1.04 and $1.1 \mathrm{~mm} / \mathrm{s}$, and a $\Delta$ between 2.38 and $2.49 \mathrm{~mm} / \mathrm{s}$, the second yielded $\delta$ of 1.08 $1.15 \mathrm{~mm} / \mathrm{s}$ and $\Delta$ of $2.13-2.34$ $\mathrm{mm} / \mathrm{s}$ and the third gave $\delta$ of $1.07-1.13 \mathrm{~mm} / \mathrm{s}$, and $\Delta$ of 1.54 $1.71 \mathrm{~mm} / \mathrm{s}$. Additionally, the spectrum from the black sample features a fourth different doublet with $\delta=0.78 \mathrm{~mm} / \mathrm{s}$ and $\Delta=1.22 \mathrm{~mm} / \mathrm{s}$. 

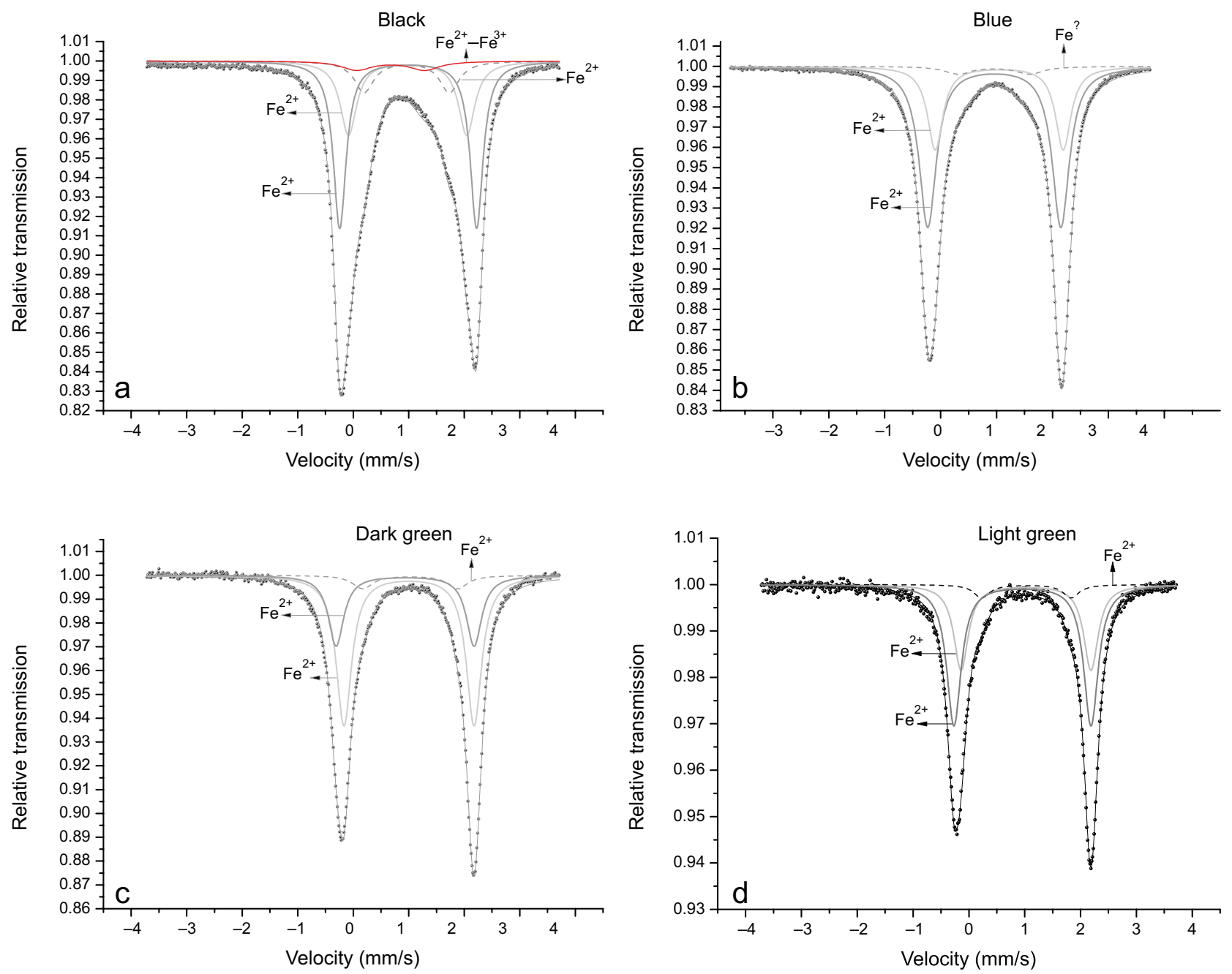

Fig. 3 Room-temperature Mössbauer spectra for black tourmaline (a), blue tourmalines (b) dark green tourmalines (c) and light green tourmalines (d).

\subsection{Optical spectroscopy (UV-VIS)}

The optical spectra of all the powdered tourmalines show intense UV absorption edges (Figs 4-5).

The spectrum of the black tourmaline shows a very high absorbance in the entire visible region. Prominent bands at c. $780 \mathrm{~nm}, 730 \mathrm{~nm}, 670 \mathrm{~nm}$ as well as smaller bands at $c .550$ $\mathrm{nm}$ and $430 \mathrm{~nm}$ were observed (Fig. 4). The spectrum of blue tourmalines displays bands at c. $730 \mathrm{~nm}$ and $670 \mathrm{~nm}$ as well as very weak bands at $550 \mathrm{~nm}$ and

Fig. 4 Optical spectra from black, blue and pink tourmalines.

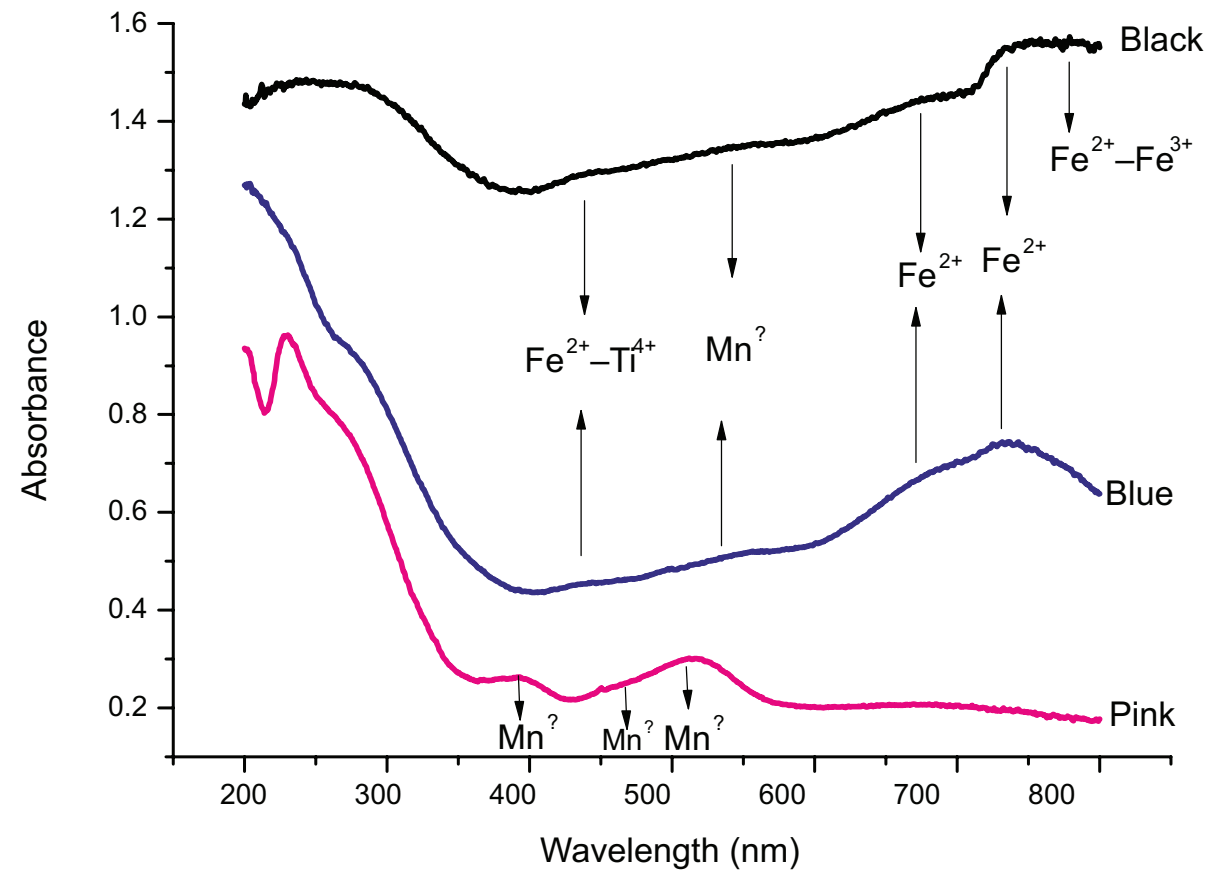




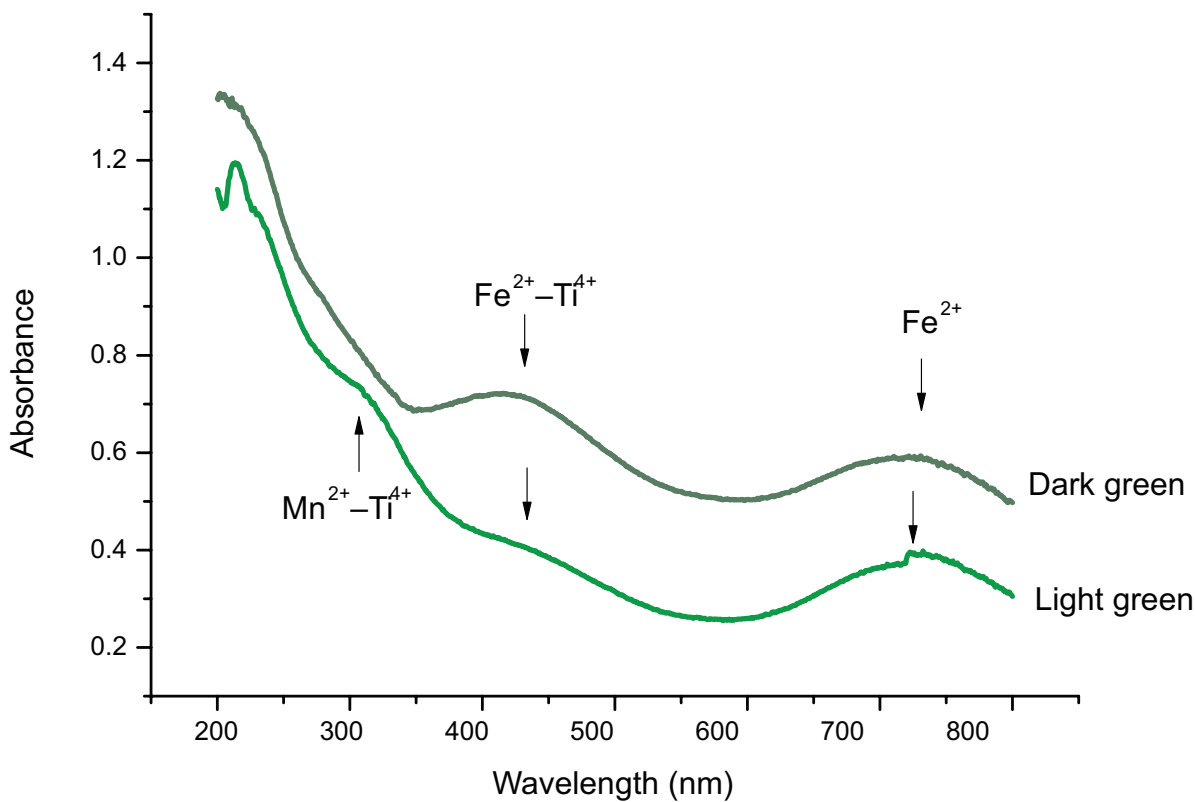

Fig. 5 Optical spectra from dark green and light green tourmalines.
$430 \mathrm{~nm}$ (Fig. 4). The spectrum of pink tourmalines (Fig. 4) yielded absorption bands at c. $395 \mathrm{~nm}, 460 \mathrm{~nm}$ and $512 \mathrm{~nm}$.

The spectra of light green and dark green tourmalines (Fig. 5) feature two main common absorption bands: at c. $430 \mathrm{~nm}$ and c. $730 \mathrm{~nm}$ that are more intense in the latter sample. Additionally, there is a band at $320 \mathrm{~nm}$ in the light green spectrum overlapping partly with its UV absorption edge.

\section{Discussion}

As the studied tourmaline crystals have very low contents of $\mathrm{V}_{2} \mathrm{O}_{3}$ and $\mathrm{Cr}_{2} \mathrm{O}_{3}$ (up to 0.08 wt. \%), the main transition metals that could contribute to the color origin are $\mathrm{Fe}, \mathrm{Mn}$ and $\mathrm{Ti}$.

The decreasing FeO content can be related to the colors in the following order: black, blue, dark green and light green. Because the pink sample shows the highest $\mathrm{Mn}-\mathrm{Fe}$ fractionation, and the lowest $\mathrm{FeO}$ and $\mathrm{TiO}_{2}$ contents (with only amounts of the order $0.0 \mathrm{X}$ wt. \%), the transitions related to the $\mathrm{Fe}$ and $\mathrm{Ti}$ are expected to have very low intensities, and the $\mathrm{Mn}$ is considered to be the main transition metal of this color.

Regarding the Mössbauer spectroscopy results (Tab. 3), the three doublets from dark green and light green tourmaline spectra were ascribed to $\mathrm{Fe}^{2+}$ at $Y$ site with different nearest-neighbor coordination environments (following Dyar et al. 1998; Pieczka et al. 1998; Castañeda et al. 2006b; Andreozzi et al. 2008). This interpretation agrees with various structure refinement studies performed on Li-bearing tourmalines which showed that the $Z$ site is typically fully populated by Al (e.g., Bosi et al. 2013; Ertl et al. 2013).
The Mössbauer spectra are mutually well comparable except for two doublets in black $(\delta=0.78 \mathrm{~mm} / \mathrm{s}$ and $\Delta=$ $1.22 \mathrm{~mm} / \mathrm{s})$ and blue $(\delta=1.06 \mathrm{~mm} / \mathrm{s}$ and $\Delta=1.28 \mathrm{~mm} / \mathrm{s})$ tourmalines with rather low values of quadrupole splitting $\Delta$ (Tab. 3). Doublets similar to the former have been commonly related to electron delocalization and they have been mainly ascribed to $\mathrm{Fe}^{2.5+}$, i.e. intervalence charge transfer (IVCT) interactions, at least partly, between $\mathrm{Fe}^{2+}$ and $\mathrm{Fe}^{3+}$ ions located in adjacent sites (e.g., Saegusa et al. 1979; Kraczka and Pieczka 2001; Andreozzi et al. 2008; Filip et al. 2012). Therefore, we relate the fourth doublet of the black tourmaline spectrum to $\mathrm{Fe}^{2+}-\mathrm{Fe}^{3+}$ IVCT.

On the other hand, the third doublet in the blue tourmaline spectrum could represent either $\mathrm{Fe}^{2.5+}$ or $\mathrm{Fe}^{2+}$ at the $Z$ site; neither of these assignments matches well with the ranges listed in the comprehensive study of Andreozzi et al. (2008). However, it most likely represents $\mathrm{Fe}^{2.5+}$ at the $Y$ adjacent sites, with regard to the study of Watenphul et al. (2017) who showed that especially in the elbaite structure, $\mathrm{Fe}^{2+}$ has a very small tendency for disorder over the $Y$ and $Z$ sites. Some studies (e.g. Pieczka et al. 1998) also assigned doublets with low quadrupole splitting values (down to about $1.2 \mathrm{~mm} / \mathrm{s}$ ) to the presence of $\mathrm{Fe}^{2+}$ at $Y$ site. In any case, the doublet $\delta$ and $\Delta$ values are anomalous and cannot be unequivocally interpreted based solely on the Mössbauer data.

Based on the literature data (Taran et al. 2015), the intense UV absorption edge shown in all our optical spectra could originate from some electronic charge-transfer transitions of the ligand-to-metal type. However, it is not possible to decipher which cation is involved in this process as all samples show the same feature.

The absorbance of the spectra in the $730 \mathrm{~nm}$ region correlates positively with the $\mathrm{FeO}$ contents determined 
Tab. 4 Interpretation of the optical spectroscopy results combined with Mössbauer spectroscopy and the main transition metal contents

\begin{tabular}{|c|c|c|c|c|c|c|}
\hline Color & $\begin{array}{c}\mathrm{FeO} \\
\text { (wt. \%) }\end{array}$ & $\begin{array}{c}\mathrm{TiO}_{2} \\
\text { (wt. \%) }\end{array}$ & $\begin{array}{c}\mathrm{MnO} \\
\text { (wt. \%) }\end{array}$ & Mössbauer & Main absorption bands & Likely assignments \\
\hline \multirow{4}{*}{ black } & \multirow{4}{*}{$13.85-14.26$} & \multirow{4}{*}{$0.12-0.25$} & \multirow{4}{*}{$0.13-0.27$} & \multirow{3}{*}{$\begin{array}{l}\mathrm{Fe}^{2+}(Y 1), \mathrm{Fe}^{2+}(Y 2), \\
\mathrm{Fe}^{2+}(Y 3)\end{array}$} & $\sim 730 \mathrm{~nm}, \sim 670 \mathrm{~nm}$ & $\mathrm{Fe}^{2+} \mathrm{d}-\mathrm{d}$ transition \\
\hline & & & & & $\sim 780 \mathrm{~nm}$ & $\mathrm{Fe}^{2+}-\mathrm{Fe}^{3+}$ IVTC \\
\hline & & & & & $\sim 550 \mathrm{~nm}$ & $\mathrm{Mn}^{?} \mathrm{~d}-\mathrm{d}$ transition \\
\hline & & & & $\mathrm{Fe}^{2.5+}$ & $\sim 430 \mathrm{~nm}$ & $\mathrm{Fe}^{2+}-\mathrm{Ti}^{4+}$ IVTC \\
\hline \multirow{3}{*}{ blue } & \multirow{3}{*}{$7.94-8.73$} & \multirow{3}{*}{$0.00-0.15$} & \multirow{3}{*}{$0.31-0.44$} & $\mathrm{Fe}^{2+}(Y 1), \mathrm{Fe}^{2+}(Y 2)$ & $\sim 730 \mathrm{~nm}, \sim 670 \mathrm{~nm}$ & $\mathrm{Fe}^{2+} \mathrm{d}-\mathrm{d}$ transition \\
\hline & & & & $\mathrm{Fe}^{2.5+}$ or $\mathrm{Fe}^{2+}(?)$ & $\sim 550 \mathrm{~nm}$ & $\mathrm{Mn}^{?} \mathrm{~d}-\mathrm{d}$ transition \\
\hline & & & & & $\sim 430 \mathrm{~nm}$ & $\mathrm{Fe}^{2+}-\mathrm{Ti}^{4+}$ IVTC \\
\hline \multirow{2}{*}{ dark green } & \multirow{2}{*}{$3.78-6.02$} & \multirow{2}{*}{$0.12-0.36$} & \multirow{2}{*}{$0.57-1.00$} & $\mathrm{Fe}^{2+}(Y 1), \mathrm{Fe}^{2+}(Y 2)$, & $\sim 730 \mathrm{~nm}$ & $\mathrm{Fe}^{2+} \mathrm{d}-\mathrm{d}$ transition \\
\hline & & & & $\mathrm{Fe}^{2+}(Y 3)$ & $\sim 430 \mathrm{~nm}$ & $\mathrm{Fe}^{2+}-\mathrm{Ti}^{4+}$ IVTC \\
\hline \multirow{3}{*}{ light green } & \multirow{3}{*}{$1.67-1.91$} & \multirow{3}{*}{$0.03-0.30$} & \multirow{3}{*}{$0.88-1.18$} & $\mathrm{Fe}^{2+}(Y 1), \mathrm{Fe}^{2+}(Y 2)$, & $\sim 730 \mathrm{~nm}$ & $\mathrm{Fe}^{2+} \mathrm{d}-\mathrm{d}$ transition \\
\hline & & & & $\mathrm{Fe}^{2+}(Y 3)$ & $\sim 430 \mathrm{~nm}$ & $\mathrm{Fe}^{2+}-\mathrm{Ti}^{4+} \mathrm{IVTC}$ \\
\hline & & & & & $\sim 320 \mathrm{~nm}$ & $\mathrm{Mn}^{2+}-\mathrm{Ti}^{4+} \mathrm{IVTC}$ \\
\hline \multirow{3}{*}{ pink } & \multirow{3}{*}{$0.00-0.05$} & \multirow{3}{*}{$0.00-0.06$} & \multirow{3}{*}{$0.11-0.59$} & \multirow{3}{*}{-} & $\sim 395 \mathrm{~nm}$ & $\mathrm{Mn}^{?} \mathrm{~d}-\mathrm{d}$ transition \\
\hline & & & & & $\sim 460 \mathrm{~nm}$ & or \\
\hline & & & & & $\sim 512 \mathrm{~nm}$ & $\mathrm{Mn}^{2+}-\mathrm{Mn}^{3+}$ IVTC \\
\hline
\end{tabular}

by the EMPA as they increased in the same order: light green, dark green, blue and black. Bands in this region are often related to $\mathrm{Fe}^{2+}$ (e.g., Mattson and Rossman 1987; Castañeda et al. 2006b). Therefore, in accordance with the our results of Mössbauer spectroscopy that indicate the presence of ferrous iron in all these samples, the bands at $c .730 \mathrm{~nm}$ and $670 \mathrm{~nm}$ (Tab. 4) are assigned to $\mathrm{d}-\mathrm{d}$ electronic transitions of $\mathrm{Fe}^{2+}$.

$\mathrm{A} \mathrm{Fe}^{2+}-\mathrm{Fe}^{3+}$ IVCT is considered to be the cause of the absorption at $780 \mathrm{~nm}$ in the optical spectra of the black tourmaline based on the Mössbauer spectroscopy results.

The band at $430 \mathrm{~nm}$ that is prominent in the optical spectra of the dark green and light green tourmalines, is assigned to $\mathrm{Fe}^{2+}-\mathrm{Ti}^{4+}$ IVCT following Rossman and Mattson (1986), Mattson and Rossman (1988) and Rossman (2014). This assignment is corroborated by the chemical data, since the $\mathrm{FeO}$ and $\mathrm{TiO}_{2}$ contents are greater in the dark green sample than in the light green one, similarly to the intensity of this band (Fig. 5, Tab. 4). In addition, band near $320 \mathrm{~nm}$ is assigned to the $\mathrm{Mn}^{2+}-\mathrm{Ti}^{4+}$ charge transfer (Rossman and Mattson 1986), considering that the light green tourmaline has the greatest $\mathrm{MnO}$ content among all the tourmaline varieties studied here (Tab. 4).

Absorption bands at c. $395 \mathrm{~nm}$ and $512 \mathrm{~nm}$ were already assigned in previous pink tourmaline studies to $\mathrm{d}-\mathrm{d}$ transitions of $\mathrm{Mn}^{3+}$ at the $Y$ sites (e.g., Liu et al. 2011; Maneewong et al. 2016), and bands at c. 460 and 520 $\mathrm{nm}$ were related to transitions of $\mathrm{Mn}^{2+}$ in magnetically non-equivalent sites (Castañeda et al. 2006a). The pink color in tourmalines could also result from intervalence charge transfer between $\mathrm{Mn}^{2+}$ and $\mathrm{Mn}^{3+}$ (see review of Pezzotta and Laurs 2011). Thus, it is still possible that some of the bands encountered in the pink spectra could span from $\mathrm{Mn}^{2+}-\mathrm{Mn}^{3+}$ IVCT.
A band at $550 \mathrm{~nm}$, found in blue and black tourmaline spectra, is also related to the transitions of Mn cations.

\section{Conclusions}

Tourmalines from the Mata Azul Pegmatitic Field, central Brazil, with different colors were characterized using electron-microprobe analyses, Mössbauer spectroscopy and ultraviolet-visible range (UV-VIS) optical spectroscopy. The following conclusions were obtained:

- The black color is formed by high absorbance in all regions of the visible spectra caused by $\mathrm{Fe}^{2+}-\mathrm{Fe}^{3+}$ IVCT $(780 \mathrm{~nm}), \mathrm{Fe}^{2+} \mathrm{d}-\mathrm{d}$ transitions $(730 \mathrm{~nm}, 670 \mathrm{~nm})$, $\mathrm{Fe}^{2+}-\mathrm{Ti}^{4+}$ IVCT $(430 \mathrm{~nm})$ and transitions related to $\mathrm{Mn}$ cations $(550 \mathrm{~nm})$;

- The blue color is distinguished from green colors by the higher absorbance in the $730 \mathrm{~nm}$ region $\left(\mathrm{Fe}^{2+} \mathrm{d}-\mathrm{d}\right.$ transitions), and the higher $\mathrm{FeO}$ content, as well as a lower absorbance in the $430 \mathrm{~nm}$ region and a lower $\mathrm{TiO}_{2}$ content;

- The green colors are associated with absorption bands at $730 \mathrm{~nm}\left(\mathrm{Fe}^{2+} \mathrm{d}-\mathrm{d}\right.$ transitions $)$ and $430 \mathrm{~nm}\left(\mathrm{Fe}^{2+}-\mathrm{Ti}^{4+}\right.$ IVCT);

- The light green color has a lower absorbance compared to the dark green and an additional band at $320 \mathrm{~nm}$ $\left(\mathrm{Mn}^{2+}-\mathrm{Ti}^{4+}\right.$ IVCT $)$;

- The pink color is a result of the high Mn-Fe fractionation. It was not possible to assure the oxidation states of the Mn cations. The existence of $\mathrm{Mn}^{2+}-\mathrm{Mn}^{3+}$ IVCT is also possible.

This work contributes to increasing the available comprehensive chemical and spectroscopic data of tourmalines. Furthermore, this is the first detailed chemical and spectroscopy study of tourmalines from the granitic 
pegmatites of central Brazil. The results can be used to support future studies in treatments for color enhancement in tourmalines from the Mata Azul Pegmatitic Field and in similar tourmalines.

Acknowledgements. The FAP-DF Ms.C scholarship to Simone F. da Silva is gratefully acknowledged. We are indebted to Nilson F. Botelho for the electron-microprobe analysis and the beneficial discussion, to Cristiano Fantini for allowing us to use the UV-VIS laboratory and to Professor Geraldo Rezende de Andrade in memoriam, to whom the tourmaline samples belonged before they were stored at the Institute of Geosciences of the University of Brasília. We also want to thank Andy Tindle, Julie Selway and Jian Xiong for the Excel ${ }^{\mathrm{TM}}$ worksheet used for the calculation of structural formulae of tourmaline (downloaded from Tindle's website), the handling editor J. Cempírek for improving the quality of the manuscript and the reviewers J. Fridrichová and A. Pieczka for their advices and fruitful suggestions.

Electronic supplementary material. A table containing the complete electron-microprobe analyses of the studied tourmalines is available online at the Journal web site (http://dx.doi.org/10.3190/jgeosci.258).

\section{References}

Alvarenga CJS, Botelho NF, Dardene MA, Lima ONB, MaCHADO MA (2007) Geologia da folha Cavalcante SD.23-V-C-V $1: 100.000$

Andreozzi GB, Bosi F, Longo M (2008) Linking Mössbauer and structural parameters in elbaite-schorl-dravite tourmalines. Amer Miner 93: 658-666

Bosi F, Andreozzi GB, Skogby H, Lussier AJ, Abdu Y, Hawthorne FC (2013) Fluor-elbaite, $\mathrm{Na}\left(\mathrm{Li}_{1.5} \mathrm{Al}_{1.5}\right)$ $\mathrm{Al}_{6}\left(\mathrm{Si}_{6} \mathrm{O}_{18}\right)\left(\mathrm{BO}_{3}\right)_{3}(\mathrm{OH})_{3} \mathrm{~F}$, a new mineral species of the tourmaline supergroup. Amer Miner 98: 297-303

Castañeda C (2002) Caracterização Mineralógica de Amostras Naturais e Tratadas de Turmalinas e Morganitas do Distrito Pegmatítico de Araçuaí, Minas Gerais. Unpublished PhD Thesis, Universidade de Brasília, Brasília, pp 1-230

Castañeda C, Botelho NF, Krambrock K, Dantas MS, Pedrosa-SoAres AC (2006a) Centros paramagnéticos em elbaíta rosa natural e irradiada. GEONOMOS 14: $7-15$

Castañeda C, Eeckhout SG, da Costa GM, Botelho, NF, De Grave, E (2006b) Effect of heat treatment on tourmaline from Brazil. Phys Chem Miner 33: 207-216

Cuadros FA, Botelho NF, Fuck RA, Dantas EL (2017a) The Ticunzal Fm. in central Brazil: record of Rhyacian sedimentation and metamorphism in the western border of the São Francisco Craton. J South Am Earth Sci 79: 307-325

Cuadros FA, Botelho NF, Fuck RA, Dantas EL (2017b) The peraluminous Aurumina Granite Suite in central Brazil: an example of mantle-continental crust interaction in a Paleoproterozoic Cordilleran hinterland setting? Precambr Res 299: 75-100

ČERNÝ P (1990) Distribution, affiliation and derivation of rare-element granitic pegmatites in the Canadian Shield. Geol Rundsch 79: 183-226

ČERNÝ P (1991) Rare-element granitic pegmatites. Part I Anatomy and internal evolution of pegmatite deposits. Geosci Can 18: 49-67

ČERNÝ P, ERCIT TS (2005) The classification of granitic pegmatites revisited. Canad Mineral 43: 2005-2026

de Almeida FFM, Hasui Y, DE Brito Neves BB, Fuck RA (1981) Brazilian structural provinces: an introduction. Earth Sci Rev 17: 1-29

DARDEnNe MA (2000) The Brasília Fold Belt. In: CoRdani UG, Milani EJ, Thomaz Filho A, Campos DA (eds) Tectonic Evolution of South America. $31^{\text {st }}$ International Geological Congress, SBG, Rio de Janeiro, pp 231-263

DyAr MD, TAYlor ME, Lutz TM, Francis CA, GuidotTi CV, WisE M (1998) Inclusive chemical characterisation of tourmaline: Mössbauer study of Fe valence and site occupancy. Amer Miner 83: 848-864

Ertl A, Giester G, Schüssler U, Brätz H, OKrusch M, Tillmanns E, BANK H (2013) Cu- and Mn-bearing tourmalines from Brazil and Mozambique: crystal structures, chemistry and correlations. Mineral Petrol 107: 265-279

Filip J, Bosi F, Novák M, Skogby H, Tuček J, Čuda J, WILDNER M (2012) Iron redox reactions in the tourmaline structure: high-temperature treatment of $\mathrm{Fe}^{3+}$-rich schorl. Geochim Cosmochim Acta 86: 239-256

Henry DJ, Dutrow BL (2012) Tourmaline at diagenetic to low-grade metamorphic conditions: its petrologic applicability. Lithos 154: 16-32

Henry DJ, Novák M, Hawthorne FC, Ertl A, Dutrow BL, Uher P, Pezzotta F (2011) Nomenclature of the tourmaline-supergroup minerals. Amer Miner 96: 895-913

KraczKa J, PieczKa A (2001) Crystallochemical structure of tourmalines inferred from Mössbauer spectroscopy. Acta Phys Pol A 100: 743-750

Krambrock K, Pinheiro MVB, Medeiros SM, Guedes KJ, SchweIzer S, Spaeth JM (2002) Investigation of radiation-induced yellow color in tourmaline by magnetic resonance. Nucl Instrum Methods Phys Res 191: 241-245

Krambrock K, Pinheiro MVB, Medeiros SM, Guedes KJ, Schweizer S, Spaeth JM (2004) Correlation of irradiation-induced yellow color with the O-hole center in tourmaline. Phys Chem Miner 31: 168-175 
LaCERda Filho JV, Resende A, Silva A (1999) Geologia e recursos minerais do estado de Goiás e Distrito Federal. Programa levantamentos geológicos básicos do Brasil. CPRM/METAGO/UnB, Goiânia, Mapa geológico e de recursos mineral, escala 1:500 000

LiU X, Feng X, Fan J, Guo S (2011) Optical absorption spectra of tourmaline crystals from Altay, China. Chinese Opt Lett 9: 1-4

Maneewong A, Seong BS, Shin EJ, Kim JS, Kajornrith V (2016) Color change of tourmaline by heat treatment and electron beam irradiation: UV-Visible, EPR, and Mid-IR spectroscopic analyses. J Korean Phys Soc 68: 83-92

MARQues G (2009) Geologia dos Grupos Araí e Serra da Mesa e Seu Embasamento no Sul de Tocantins. Unpublished MSci thesis, University of Brasília, Brasília, pp 1-116

Mattson SM, Rossman GR (1987) $\mathrm{Fe}^{2+}-\mathrm{Fe}^{3+}$ interactions in tourmaline. Phys Chem Miner 14: 163-171

MatTSON SM, Rossman GR (1988) $\mathrm{Fe}^{2+}-\mathrm{Ti}^{4+}$ charge transfer in stoichiometric $\mathrm{Fe}^{2+}, \mathrm{Ti}^{4+}$-minerals. Phys Chem Miner 16: 78-82

Pezzotta F, Laurs BM (2011) Tourmaline: the kaleidoscopic gemstone. Elements 7: 333-338

PieczKa A, KraczKa J, ŻabińsKi W (1998) Mössbauer spectra of $\mathrm{Fe}^{3+}$-poor schorls: reinterpretation on the basis of ordered structure model. J Czech Geol Soc 43: 69-74

Polo HJO, Diener FS (2013) Carta geológica: folha Mata Azul SD.22-X-DII. Projeto Noroeste de Goiás, CPRMCompanhia de Pesquisa de Recursos Minerais, Goiânia

QueIroz HA (2016) Sistema Granítico-Pegmatítico Mata Azul: Caracterização e Gênese. Unpublished $\mathrm{PhD}$ thesis, University of Brasília, Brasília, pp 1-131

QueIroz HA, Botelho NF (2017) Fosfatos de Fe e Mn primários e secundários em pegmatitos graníticos do
Campo Pegmatítico Mata Azul, Jaú do Tocantins, TO, Brasil. Geol USP Série Científica 17: 159-168

Queiroz HA, Botelho NF (in print) The Mata Azul pegmatitic field, Tocantins/Goiás, central Brazil: geology, genesis and mineralization. Brazil J Geol (doi: 10.1590/2317-4889201820170048)

Rossman GR (2014) Optical spectroscopy. In: HeNDERSON GS, Neuville DR, Downs RT (eds) Spectroscopy Methods in Mineralogy and Materials Sciences. Reviews in Mineralogy and Geochemistry 78: 371-398

Rossman GR, MATTSON SM (1986) Yellow, Mn-rich elbaite with $\mathrm{Mn}-\mathrm{Ti}$ intervalence charge transfer. Amer Miner 71: 599-602

Saegusa N, Price D, Smith G (1979) Analysis of the Mössbauer spectra of several iron-rich tourmalines (schorls). J Phys Colloques 40: C2-456-C2-459

Taran MN, Dyar MD, Naumenko I V., Vyshnevsky OA (2015) Spectroscopy of red dravite from northern Tanzania. Phys Chem Miner 42: 559-568

Tindle AG, Breaks FW, Selway JB (2002) Tourmaline in petalite-subtype granitic pegmatites: evidence of fractionation and contamination from the Pakeagama Lake and Separation Lake areas of northwestern Ontario, Canada. Canad Mineral 40: 753-788

Valeriano CM, Dardenne MA, Fonseca MA, Simões LSA, SEER HJ (2004) A evolução tectônica da Faixa Brasília. In: MAntesso-Neto V, BARTorelli A, CARneiro CDR, Brito-Neves BB (eds) Geologia do Continente Sul-Americano: Evolução da Obra de Fernando Flávio Marques de Almeida. Beca, São Paulo, pp 575-593

Watenphul A, Malcherek T, Wilke FDH, Schlüter J, Mirailova B (2017) Composition-thermal expandability relations and oxidation processes in tourmaline studied by in situ Raman spectroscopy. Phys Chem Miner 44: 735-748 